\title{
The Effect of Extensive Reading on Students' Reading Comprehension
}

\begin{tabular}{|c|c|c|}
\hline \multicolumn{3}{|c|}{${ }^{1}$ Dadan Hidayat, ${ }^{2}$ Titi Dewi Rohati } \\
\hline e-mail : ${ }^{1,2}{ }^{1}$ & $\begin{array}{l}\text { s Bina Saran } \\
\text { q @ bsi.ac.id }\end{array}$ & $\begin{array}{l}\text { latika } \\
\text { @ bsi.ac.id }\end{array}$ \\
\hline Diterima & Direvisi & Disetujui \\
\hline $22-01-2020$ & $23-02-2020$ & $28-02-2020$ \\
\hline
\end{tabular}

\begin{abstract}
Reading is an important skill in learning English but sometimes students get some problems in the reading process because they limited vocabulary knowledge so that they poor in comprehension and they difficult to recall information after reading. The teachers need to help the students to resolve these problems with refining their technique in teaching reading. The teachers need to help students fall in love with a book first. The aim of this research to give information about extensive reading activities in the reading process in SMAN Lewigoong Limbangan. The writer used the quantitative as the researched method and the writer used the queasy experiment as the research design. For collecting the data the writer gave the pre-test and post-test to compare students' achievement in reading comprehension before and after extensive reading imply in the reading process. The respondents for the experimental class are 30 students. The researcher used SPSS 20 program to analyze the data to find out whether there is an effect on students reading comprehension after extensive reading applied in the reading process. Based on the finding and discussion. It can be concluded that the hypothesis was accepted. It meant that there was an effect of extensive reading on student reading comprehension. Based on the resulted of this research. The writer suggested the teacher use extensive reading on the reading process to improved student reading comprehension because it proved by students score in posttest was better than pre-test.
\end{abstract}

Key words: Teaching, Extensive reading and Reading Comprehension.

Abstrak - Membaca adalah keterampilan yang penting dalam belajar bahasa Inggris tetapi kadang-kadang siswa mendapatkan beberapa masalah dalam proses membaca karena kosakata yang dikuasi sangat sedikit sehingga mereka kurang dalam pemahaman dan mereka sulit mengingat informasi setelah membaca. Para guru perlu membantu siswa untuk menyelesaikan masalah ini dengan menyempurnakan teknik mereka dalam mengajar membaca. Para guru perlu membantu siswa jatuh cinta dengan buku terlebih dahulu. Tujuan dari penelitian ini untuk memberikan informasi tentang metode extensive reading dalam proses pembelajaran membaca di SMAN Lewigoong Limbangan. Penulis menggunakan metode penelitian kuantitatif dan quasy eksperimel sebagai desain penelitian. Untuk mengumpulkan data, penulis memberikan pre-test dan post-test untuk membandingkan prestasi siswa dalam pemahaman membaca sebelum dan sesudah metode extensive reading di terapkan dalam proses pembelajaran membaca. Responden untuk kelas eksperimen adalah 30 siswa. Peneliti menggunakan program SPSS 20 untuk menganalisis data dan untuk mengetahui apakah ada efek pada pemahaman membaca siswa setelah metode extensive reading diterapkan dalam proses membaca. Berdasarkan temuan dan diskusi. Dapat disimpulkan bahwa hipotesis diterima. Ini berarti bahwa ada efek dari metode extensive reading terhadap pemahaman siswa. Berdasarkan hasil penelitian ini. Penulis menyarankan guru menggunakan metode extensive reading pada proses membaca untuk meningkatkan pemahaman membaca siswa karena terbukti skor siswa pada post-test lebih baik daripada pre-test.

Kata Kunci: Mengajar, Extensive Reading, Pemahaman Membaca

\section{INTRODUCTION}

Reading is important for students to get information and increase their knowledge. Reading is very useful for us to get knowledge as (Patel, 2008) stated that Reading is most useful and important skill for people. This skill is more important than speaking and writing. Reading is a source of joys. Good reading is that which keeps students regular in reading which provide him both pleasure and profit. Student's sometime face some problems in reading process due to reading is a complex activity as (Pang \& Bernhardt, 2003) stated that "Reading is about understanding written texts. It is a complex activity that involves both perception and thought. Reading consists of two related processes: word recognition and comprehension. Word recognition refers to the process of perceiving how written symbols correspond to one's spoken language. 
Comprehension is the process of making sense of words, sentences and connected text".

There some problems that caused the student poor of comprehension. One of factor who caused the student poor comprehension is the Limited vocabulary knowledge as (Westwood, 2001) stated that "If a student has difficulty understanding what he or she is reading, it is worth considering whether there is a serious mismatch between the student's own knowledge of word meanings (expressive and listening vocabulary) and the words used in the text". It is clear that if students have limited vocabulary knowledge will cause the poor comprehension. The other factors that make students poor of comprehension are recalling information after reading. Recalling after reading is important for the reader so that they know the detail of the texts and they can resume what detail on the texts after reading. (Westwood, 2001) stated that "Recall is dependent partly upon factors such as vividness and relevance of the information in the text; but it is also dependent upon a student giving adequate attention to the reading task and knowing that it is important to remember details". The other factor that make student poor of comprehension is the teacher / tutor give the unfamiliar the subject matter in the classroom to students. Using the school textbook as the medium for first introducing new information to students is not usually the most effective method of delivery. The teacher need to give some information before teacher reading as (Westwood, 2001) stated that" It is better to provide information first by other means (e.g. video, posters, minilecture, discussion) to build firm background knowledge before students are expected to read about that theme in printed texts". These three factors need to be refining by the teacher or tutor. So that the students can face these problems and they can comprehend the text correctly and they become a good reader.

The previous paragraph tells about student's problem in reading process and one of the students' problem is limited vocabulary knowledge. This is the teacher job to manage and help students to resolve this problem so that they have vocabulary knowledge. There some strategies for building a powerful vocabulary in reading process as (Mickulecky, 2007) stated that the strategies for building a powerful vocabulary in reading process are "Check your knowledge of the words used most frequently in English, Focus on the words used in academic texts, Use the dictionary effectively, Keep a vocabulary notebook, Use study cards". These strategies are interesting to discuss in this section. One of them is keep a vocabulary notebook, it is important for students to keep a vocabulary notebook for memorizing by them. It can help them to build the vocabulary knowledge, as (Mickulecky, 2007) stated that "When you encounter new words, write them in a notebook that you use only for vocabulary and not for other course work. (A small notebook is preferable so you can carry it around with you.) This notebook will help you study vocabulary more effectively. With all your words in one place in the notebook, you can easily check your knowledge of words you have studied before". How to organize and use the notebook in reading process as (Mickulecky, 2007) stated that to organize and use the notebook are "Decide on a method for putting words in order, use two pages in the notebook, check your knowledge of the words by covering one of the pages and trying to remember the information on the other". The other strategy to build the vocabulary knowledge is Use study cards. It is important for student to memorize the new vocabulary in reading process as (Mickulecky, 2007) stated that "Study cards can help you review words and make them part of your permanent vocabulary. When you have made a set of cards, carry them with you and test yourself often. Add new words that you encounter and want to learn. You should not remove a word from your set until you are completely sure of the meaning and can recall it instantly".

The important thing in reading process is how to comprehend the texts and how to record detail on the texts after reading. In previous paragraphs told about the student problem in reading process and how to solve this problem. Students have to record detail in the texts after reading. It means that we have to skill to comprehend the texts because comprehension is not only how to record word by word but how to remember the main idea and detail in the reading texts because "Comprehending what you read is more than just recognizing and understanding words. True comprehension means making sense of what you read and connecting the ideas in the text to what you already know. It also means remembering what you have read. In other words, comprehending means thinking while you read, (Mickulecky, 2007). "Good teacher of reading starts with an understanding of what reading is, what exactly happens between the text, brain and eye, (Santamaria, 2017)." Be good teacher will create their students be a good reader, there some strategies for student to make their students become a good reader, "these are helping children fall in love with book, create a space every day for sustained, silent reading and allow children to make choices about their reading material,(Johnson, 2008)." 
The teachers need to help the students fall in love with book by giving student's choice about their material. It is also related to this research with the effect of extensive reading activities on students reading comprehension. Extensive reading is an approach to language teaching in which learners read a lot of easy material in the new language. They choose their own reading material and read it independently of the teacher. They read for general, overall meaning, and they read for information and enjoyment. They are encouraged to stop reading if the material is not interesting or if it is too difficult. They are also encouraged to expand their reading comfort zone - the range of material that can be read easily and with confidence (Bamford \& Day, 2003) based on the above explanation, it proves that extensive reading help the reader more enjoy in reading process because they read for pleasure then they read what they want. The material in extensive reading will be selected from lower to high as (Patel, 2008) stated that Material for extensive reading will be selected at a lower level of difficulty than that for intensive reading. Extensive reading same with silent reading and this technique has some advantages. According to (Patel, 2008) stated that the advantages of extensive reading are this reading makes students very active and accurate, silent reading concentrates the attention of learners toward subject matter and he learns naturally, It saves time because this activity is done at a time. All students participate together in this activity at a time. It is very useful to develop the skill of reading fast

Based on the above explanation, there some problem need to be refine in reading process to make student fall in love with book and they are not poor of comprehension in reading process. When reading is effortless, which is likely the case for those reading this preface, it is difficult to imagine what it might be like to read print and not be able to understand it or say much about it afterward. This is the teachers/tutors job to guide the students to be a good reader. The teacher need to create a good condition for learning to read as the extensive reading is reading for pleasure. The first help children fall in love with book, "create a space every day for sustained, silent reading, allow children to make choices about their reading material, connect reading pleasure to reading practice, keep your reading program simple, keep instruction simple, make reading like real life and include talk and other form of social instruction, (Johnson, 2008). That the important things as teachers need to provide them with large chuck of time to read enjoyable books, invite them to write their ideas, and encourage them to share their insight an idea with the other students. Small bit of instruction should then be provided along the way as a teacher, we need to do more listening and looking and less talking and testing.

\section{RESEARCH METHODOLOGY}

Writer used the quantitative method for this research, because the writer need the data' to be analyzed using mathematically based method in particular statistic' Then in quantitative research method the writer gave the test for this research and the data was analyzed' by examining the relationship among variable. These variables, in turn, can be measured, typically on instruments, so that numbered data can be analyzed using statistical procedures (Creswell, 2009) . It's clear that quantitative method suitable to use for this research for research design the writer used the quasi experiment for experimental research because quasi suited to look at the effect of an educational intervention, such as a school improvement programmed, a project to improve a specific element (such as an anti- bullying programmed) or a professional development programed (Muijs Daniel, 2004). The writer used experimental class to find out whether there is effect of extensive reading on students reading comprehension. Based on explanation above the writer used the quasi experiment for experimental research because the writer tried to find out the effect of an educational intervention, such as a school improvement programmed, a project to improve a specific element. For this section the writer wants to know the effect of speed reading method on student reading comprehension.

\section{FINDING AND RESULTS}

\section{FINDING}

This chapter presents the interpretation of the instruments and the explanation of discussion in order to answer research questions about the use of the extensive reading method on students reading comprehension before and after being taught by using extensive reading on students reading comprehension. This presentation, the researcher presented and analyzed the data which had been collected through two kinds of tests, they were pretest and post-test. The pre-test was given by the researcher to find out the students' comprehension without treatment. The post-test was given by the researcher after giving the treatment by using extensive reading in the reading process. Both tests were given by the researcher to compare student comprehension before and after giving the treatment. The researcher used a test as the 
instrument for collecting the data. It was given to class X1-IPA students of SMAN Lewigoong Limbangan. The number of questions given by the researcher was 10 questions. It consisted of multiple-choice tests. There were 30 students as respondents or the subject of this research. The data of pre-test and post-test can be seen on below table.

Table 1

\section{Students Score Pre-test and Post- test}

\begin{tabular}{|c|c|c|c|}
\hline No & Subject & Pre- test & Post- test \\
\hline 1 & $\mathrm{X} 1$ & 65 & 95 \\
\hline 2 & $\mathrm{X} 2$ & 70 & 95 \\
\hline 3 & X3 & 74 & 90 \\
\hline 4 & $\mathrm{X} 4$ & 71 & 100 \\
\hline 5 & $\mathrm{X} 5$ & 61 & 100 \\
\hline 6 & X6 & 62 & 90 \\
\hline 7 & $\mathrm{X} 7$ & 75 & 80 \\
\hline 8 & $\mathrm{X} 8$ & 73 & 90 \\
\hline 9 & X9 & 72 & 80 \\
\hline 10 & $\mathrm{X} 10$ & 70 & 100 \\
\hline 11 & $\mathrm{X} 11$ & 50 & 90 \\
\hline 12 & $\mathrm{X} 12$ & 55 & 100 \\
\hline 13 & X13 & 80 & 100 \\
\hline 14 & $\mathrm{X} 14$ & 90 & 80 \\
\hline 15 & X15 & 70 & 100 \\
\hline 16 & $\mathrm{X} 16$ & 77 & 100 \\
\hline 17 & $\mathrm{X} 17$ & 75 & 80 \\
\hline 18 & $\mathrm{X} 18$ & 74 & 90 \\
\hline 19 & $\mathrm{X} 19$ & 73 & 100 \\
\hline 20 & X20 & 62 & 100 \\
\hline 21 & X21 & 62 & 80 \\
\hline 22 & $\mathrm{X} 22$ & 62 & 98 \\
\hline 23 & X23 & 60 & 76 \\
\hline 24 & X24 & 70 & 83 \\
\hline 25 & $\mathrm{X} 25$ & 70 & 90 \\
\hline 26 & X26 & 80 & 88 \\
\hline 27 & $\mathrm{X} 27$ & 80 & 75 \\
\hline 28 & $\mathrm{X} 28$ & 71 & 75 \\
\hline 29 & X29 & 70 & 75 \\
\hline 30 & X30 & 71 & 75 \\
\hline
\end{tabular}

After the researcher got the score of pretest and post- test as the above table. The researcher analyzed it by using SPSS 20 Program to find out the mean score of pre- test and post - test as below table.

Table 2

Paired Samples Statistics

\begin{tabular}{|ll|r|r|r|l|}
\hline & Mean & N & $\begin{array}{l}\text { Std. } \\
\text { Deviation }\end{array}$ & $\begin{array}{l}\text { Std. } \\
\text { Error } \\
\text { Mean }\end{array}$ \\
\hline $\begin{array}{l}\text { Pair } \\
1\end{array}$ & $\begin{array}{l}\text { PRE-TEST } \\
\text { POST- } \\
\text { TEST }\end{array}$ & 69.83 & 30 & 8.184 & 1.494 \\
\end{tabular}

Referring to the above result Paired Samples Statistics which analyzed by using SPSS 20 program. The data showed that the mean score for student pre-test 69.83 and students got the mean score for the post-test is 89.17 which standard deviation 8.184 for students in pre-test and 9.545 for standard deviation on students on post-test. Referring to that score and research observation that students got an improvement in their score for their reading comprehension. Based on the observation, the students felt confused about how to answer the question on the pre-test because they limited vocabulary knowledge and they difficult to recall the information after reading while students on the post-test did not get the problem when answer the question because they have got the treatment by using extensive reading. After that, the researcher needed to analyze the correlation between student's score of pre-test and post-test. To analyze the student's correlation score, the researcher used the SPSS 20 programs and the result can be seen on the below table.

Table 3

Paired Samples Correlations

\begin{tabular}{|ll|r|r|r|}
\hline & & N & Correlation & Sig. \\
\hline Pair 1 & $\begin{array}{l}\text { PRE-TEST \& } \\
\text { POST- TEST }\end{array}$ & 30 & .222 & .002 \\
\hline
\end{tabular}

Based on the above table, it shows that the correlations between two scores of pre-test and post-test $=0.222$ and sig $=0,002$. For interpretation of decision-based on the result of probability achievement, that is:

a) If the sig $>0.05$, means Ho is accepted

b) If the sig $<0.05$, means Ho is rejected

It shows that $\mathrm{sig}=0.002$ is lower than 0.05 means that Ho is rejected and $\mathrm{Ha}$ is accepted. So, it concluded that there is a significant correlation between pre-test and post-test scores. After the researcher analyzed the correlation between students' scores on pre-test and post-test, the researcher needs to analyze this data with Paired Samples Test, the researcher used SPSS 20 program to analyze it. This analysis will show whether there is an effect on extensive reading on students reading comprehension or not. The result can be seen on the below table.

Table 4

Paired Samples Test

\begin{tabular}{|c|c|c|c|c|c|c|}
\hline \multicolumn{5}{|c|}{ Paired Differences } & \multirow[t]{3}{*}{$\mathrm{t}$} & df \\
\hline \multirow[t]{2}{*}{ Mean } & \multirow[t]{2}{*}{$\begin{array}{l}\text { Std. } \\
\text { Devi } \\
\text { ation }\end{array}$} & \multirow[t]{2}{*}{$\begin{array}{l}\text { Std. } \\
\text { Error } \\
\text { Mean }\end{array}$} & \multicolumn{2}{|c|}{$\begin{array}{c}95 \% \\
\text { Confidence } \\
\text { Interval of the } \\
\text { Difference }\end{array}$} & & \\
\hline & & & Lower & $\begin{array}{c}\text { Uppe } \\
\text { r }\end{array}$ & & \\
\hline
\end{tabular}




\begin{tabular}{|l|r|l|l|r|r|r|r||}
\hline $\begin{array}{l}\text { Pre- } \\
\text { Test } \\
\begin{array}{l}\text { Post- } \\
\text { test }\end{array}\end{array}$ & $\begin{array}{c}19.33 \\
3\end{array}$ & $\begin{array}{l}13.88 \\
5\end{array}$ & 2.535 & 24.518 & 14.14 & 7.6 & 9 \\
27 & 29 \\
\hline
\end{tabular}

Based on the table above, the output paired samples test shows the result of compare analysis with using Ttest.Output shows mean pre-test and post-test (19.333), standard deviation (13.885), mean standard error (2.535). The lower difference (24.518), while upper different (14.149). The result test tvalue $=(7.627)$ with $\mathrm{df}=28$ and significance (0.000). The guideline of $\mathrm{T}_{\text {value }}$ and $\mathrm{T}_{\text {table }}$ where $\mathrm{df}=$ 28 got from $\mathrm{T}_{\text {table }}=1.70$. So, $\mathrm{T}_{\text {value }}(7.627)>\mathrm{T}_{\text {table }}$ (1.70) means that Ho is rejected and Ha is accepted. Therefore, it concluded that there are significant differences between pre-test and post-test scores where mean of post-test (89.17) higher than mean of pre-test (69.83) means that there is an effect on teaching reading by using extensive reading on student reading comprehension.

After the researcher analyzed T-test to find out whether there is an effect on students reading comprehension after giving the treatment by using extensive reading activities on the reading process. The researcher needs to analyze whether data on pre-test and post-test was distribution normal or not and whether the data was homogeneity or not. To analyze these steps, the researcher used SPSS 20 program. The result of the homogeneity pre-test and post-test can be seen on the below table.

Table 5

Test of Homogeneity of Variances

\begin{tabular}{|r|r|r|l|}
\hline Levene Statistic & df1 & df2 & Sig. \\
\hline 1.339 & 1 & 28 & .252 \\
\hline
\end{tabular}

\section{a. $\mathrm{H}_{0}$ : Data is homogeny \\ b. $\mathrm{H}_{1}$ : Data is not homogeny}

The standard significant of education is $0.05(\alpha=5 \%)$. Based on the output from SPSS above is known that the test called homogeny if the significant score more than 0.05. Based on the table above, the test is homogeny because of $0.252>$ 0.05. It means that $\mathrm{H} 0$ is accepter and $\mathrm{H} 1$ is rejected. So, it can be concluding that students of X-IPA homogeny of variances. After the data was analyzed by using SPSS 20 program (Suparman, 2014) and the result show that data was homogent. It means that the researcher had to continue to check the normality test of data pre-test and posttest.it was the same with homogeneity tests, the normality test also conducted for this research and the writer used SPSS 20 program. The result of the normality test can be seen on the below table.
Table 6

One-Sample Kolmogorov-Smirnov Test

\begin{tabular}{|c|c|c|c|}
\hline & & $\begin{array}{l}\text { PRE- } \\
\text { TEST }\end{array}$ & $\begin{array}{l}\text { POST- } \\
\text { TEST }\end{array}$ \\
\hline \multicolumn{2}{|l|}{$\mathrm{N}$} & 30 & 30 \\
\hline \multirow{2}{*}{$\begin{array}{l}\text { Normal } \\
\text { Parameters }^{\mathrm{a}, \mathrm{b}}\end{array}$} & Mean & 69.83 & 89.17 \\
\hline & $\begin{array}{l}\text { Std. } \\
\text { Deviation }\end{array}$ & 8.184 & 9.545 \\
\hline \multirow{3}{*}{$\begin{array}{l}\text { Most Extreme } \\
\text { Differences }\end{array}$} & Absolute & .208 & .172 \\
\hline & Positive & .097 & .165 \\
\hline & Negative & -.208 & -.172 \\
\hline \multicolumn{2}{|c|}{ Kolmogorov-Smirnov Z } & 1.140 & .941 \\
\hline \multicolumn{2}{|c|}{ Asymp. Sig. (2-tailed) } & .149 & .339 \\
\hline
\end{tabular}

a. Test distribution is Normal.

b. Calculated from data.

a. $\mathrm{H}_{0}$ : Data is in normal distribution

b. $\mathrm{H}_{1}$ : Data is not in normal distribution.

The standard significant of education is $0.05(\alpha=5 \%)$. To determine data is normal distribution or not it can be seen from the result of data normality testing. Based on the output from SPSS above is known that the significance value from pre-test is 1.140 and from the post test is 941 . Both value from pre-test and post-test are bigger than 0.05. It means that $\mathrm{H}_{0}$ is accepted and $\mathrm{H}_{1}$ is rejected and the data is in normal distribution.

The researcher need to analyzed whether the extensive reading improve students reading comprehension or not. This question will be answer by testing of hypothesis. From the data analysis it could be identify that:

1.If $\mathrm{T}_{\text {value }}>\mathrm{T}_{\text {table }}$ in $d f=28$ with the significant level 0.05. The alternative hypothesis (Ha) is accepted and the null hypothesis (Ho) is rejected. It means that there is significant different on students reading comprehension before and after giving the treatment on students reading activities by using extensive reading.

2. If $\mathrm{T}_{\text {value }}<\mathrm{T}_{\text {table }}$ in $d f=28$ with the significant level 0.05 . The null hypothesis (Ho) is accepted and the alternative hypothesis $(\mathrm{Ha})$ is rejected. It means that there is no significant different score of students reading comprehension before and after giving the treatment .The mean of students score before being taught by using extensive reading activities was (61.57). After getting treatment, the means score of students' reading comprehension were (89.17). It means that the students' score is improved.

Based on the statistical calculation using ttest, the researcher gave interpretation to $t_{\text {value }}$. First, the researcher considered the $d$.f. with the $d . f$. (30$2=28$ ). The researcher checked to the score of " $t$ " at 
the significant level of 0,05 . The $d . f$. of (28) and the critical value 0,05 significant $t_{\text {table }}$ was (1.70). By comparing the " $\mathrm{t}$ " that the researcher got in calculation $t_{\text {value }}=(7.627)$ and the value of " $t$ " on the $t_{\text {table }}=t 0.05=(1.70)$, it is known that $t_{\text {value }}$ is bigger than $t_{\text {table }}=7.627>1.70$. Because the $t_{\text {value }}$ is bigger than $t_{\text {table }}$ the null hypothesis (Ho) is rejected and the alternative hypothesis ( $\mathrm{Ha})$ is accepted. It means that there is significant different score of students reading comprehension by using extensive reading on reading process

\section{DISCUSSION}

To answer the research question for this paper is answered by using quantitative findings. Then the question for this research is;

1. Does Extensive reading improve students reading comprehension?

2. How does extensive reading give effect to student reading comprehension?

The quantitative finding answered this question. Based on the quantitative finding that extensive reading improves students reading comprehension. Then for the second answer, it can look from the quantitative finding that there is an effect of the extensive reading method on student reading comprehension after giving the treatment by using extensive reading on the student reading process. It proved by the student score on pre-test and post-test. The students' mean score on the posttest is better than the student's score on the pre-test. Although in the first meeting on the reading process. They still felt confused about how to answer the question correctly then they sometimes stopped to read if they felt that the material was difficult and if they found the difficult word from the texts. After the researcher gave the treatment to the student by using extensive reading activities on the reading process. The students feel antistatic and they knew how to answer the question correctly and they did not confuse if they found the difficult word on the texts because the researcher gave them the technique to face it. It proved by the students scored on post-test there some improvement in students reading comprehension and the researcher felt that extensive reading effective to improve students reading comprehension.

\section{CONCLUSION}

As stated before that the researcher did the research to find out the effect of extensive reading on students reading comprehension. To find out the answer to this research, the researcher compares the result of the student's pre-test and post-test. Extensive reading was done by the student in experimental. Then the extensive reading method was effective to improve reading comprehension. The statistical computation results proved that student's score on post-test $>$ students score on the pre-test. During observation when the extensive reading implied in the reading process, the students very enthusiastic, they could build their vocabulary knowledge and they could recall the information after reading. It was different before extensive reading applied in experimental class; they felt confused when they found out the new vocabulary in the reading texts and students difficult how to recall information after reading.

Several points can be drawn from the present study. First, an Extensive reading method is effective in improving students' reading comprehension. It means that the formulation of the hypothesis in Chapter 1 is accepted. Extensive reading more effective for improving student reading comprehension. It can be concluded that an extensive reading method can be used by the teacher in teaching reading activity to improve students reading comprehension. For the last conclusion, that extensive reading gives improvement for students in reading comprehension. It proved by student means score. The means score of post-test pre-test, besides that student shown their enthusiasm during the observation on the reading process when extensive reading implied in the class it means that extensive reading will help the teacher for improving students reading comprehension.

\section{BIBLIOGRAPHY}

Bamford, J., \& Day, R. R. (2003). Extensive Reading Activities for Teaching Language Edited by. The Press Syndicate of The University of Cambridge.

Creswell, J. W. (2009). Reseresch Design (Thrid Edit). Sage Publication Inc.

Johnson, A. (2008). Teaching Reading and Writing. A Division of Rowman \& Littlefield Publishers, Inc. www.rowmaneducation.com

Mickulecky, B. (2007). Advance Reading Power. Pearson Education, Inc.

Muijs Daniel. (2004). quantitative research. Sage Publications.

Pang, B. E. S., \& Bernhardt, E. B. (2003). Teaching reading. International Academy of Education. 
Patel, F. (2008). Englih Language Teaching. Sunrise Publisher \& Distributors.

Santamaria, J. (2017). Better Reading English. McGraw-Hill Education.
Suparman. (2014). Aplikasi Komputer Dalam Penyusunan Karya Ilmiah. Pustaka Mandiri.

Westwood, P. (2001). Reading and learning difficulties (B. James (ed.)). The Australian Council for Educational Research Ltd. 